\title{
Pengembangan Instrumen Penilaian Keterampilan Menggambar dan Mewarnai Siswa Kelas III Sekolah Dasar
}

\author{
Octaviani Dwi Wiranti ${ }^{1}$, Andarini Permata Cahyaningtyas ${ }^{2}$, Jupriyanto $^{3}$ \\ 1,2,3Universitas Islam Sultan Agung \\ e-mail: ${ }^{1}$ octavianidw@gmail.com, ${ }^{2}$ andarinipermata@unissula.ac.id, \\ jupriyanto@unissula.ac.id
}

\begin{abstract}
This research focused on the development of a scoring instrument for drawing and coloring skills. This step's background was based on the lack of scoring instrument and there were no specific guidelines to score the drawing and coloring skills of 3rd-grade students. This research aimed to obtain a valid scoring instrument on drawing and coloring skills, which suitable for teachers to use in the scoring process of SBdP subjects, especially visual art. The method used in this research was $R \mathcal{E D}$ by using a research design that referred to Brog and Gall's research design by doing 10 research stages. The product that resulted from this research was a scoring instrument that consists of Scoring Instrument's Grating, Student's Worksheet, Scoring Sheet, and Scoring Rubric. The results of this research were (1) The result of expert's validation obtained "Very High" criteria with an average coefficient value up to 0,864 with score details as much as 0,920, student's worksheet was 0,812, scoring sheet scores 0,884 and scoring rubric as much as 0,840. (2) The limited-scale trials' result from teachers' responses was $81,6 \%$ with the category of "Very Suitable". The students' responses towards students' worksheets obtained 98\% with "Very Suitable" category. (3) The broad-scale trials' result scores $86,8 \%$ with "Very Suitable" category. The broad-scale trials' result from students' responses scores 100\% with "Very Suitable" category. Based on the description above, therefore, the scoring instrument on drawing and coloring skills for 3rd-grade students pronounced valid and suitable to be used in the teaching process.
\end{abstract}

Keywords: Scoring Instrument, Skill, Drawing, Coloring, SBdP

Abstrak. Penelitian ini berfokus pada pengembangan sebuah instrumen penilaian keterampilan menggambar dan mewarnai. Langkah ini dilatar belakangi oleh kurangnya instrumen penilaian dan tidak adanya pedoman khusus untuk menilai keterampilan menggambar dan mewarnai untuk siswa kelas III. Tujuan dari penelitian ini yaitu untuk memperoleh instrumen penilaian keterampilan menggambar dan mewarnai yang valid dan layak digunakan oleh guru dalam proses penilaian muatan pembelajaran SBdP khususnya pada seni rupa. Penelitian ini menggunakan metode penelitian RED dengan desain penelitian yang mengacu pada desain penelitian Brog and Gall yang dilakukan dengan 10 tahap penelitian. Produk yang dihasilkan dari penelitian ini adalah instrumen penilaian yang terdiri dari Kisi-kisi Instrumen Penilaian, Lembar Kerja Siswa, Lembar Penilaian, dan Rubrik Penilaian. Hasil yang diperoleh dari penelitan ini antara lain (1) Hasil validasi ahli mendapatkan kriteria "Sangat Tinggi" dengan nilai koefisien rata-rata sebesar 0,864 dengan rincian skor untuk kisi-kisi sebesar 0,920, lembar kerja siswa adalah 0,812, lembar penilaian mendapat skor 0,884 dan untuk rubrik penilaian skornya adalah 0,840. (2) Hasil ujicoba skala terbatas dari respon guru adalah 81,6\% dengan kategori "Sangat Layak". Respon siswa terhadap lembar kerja siswa mendapatkan 98\% dengan kategori "Sangat Layak". (3) Hasil ujicoba skala luas mendapatkan skor 
sebesar 86,8\% dengan kategori "Sangat Layak". Untuk hasil ujicoba berskala luas dari respon siswa mendapatkan skor sebesar 100\% yang masuk ke dalam kategori "Sangat Layak". Berdasarkan uraian data diatas maka instrumen penilaian keterampilan menggambar dan mewarnai siswa kelas III dinyatakan valid dan layak untuk digunakan dalam proses pembelajaran.

Kata kunci : Instrumen Penilaian, Keterampilan, Menggambar, Mewarnai, SBdP

\section{PENDAHULUAN}

Saat ini proses belajar mengajar di sekolah didasarkan pada Kurikulum 2013 revisi. Kurikulum 2013 dalam pelaksanannya terfokus pada tiga aspek penilaian yaitu aspek kognitif (pengetahuan), aspek afektif (sikap) dan aspek psikomotor (keterampilan). Keterampilan yang biasa dinilai pada prose belajar mengajar di kelas III adalah keterampilan membaca, keterampilan menulis, keterampilan berbicara, keterampilan menggambar, dan lain-lain. Keterampilan menggambar sendiri termasuk kedalam muatan pelajaran Seni Budaya dan Prakarya (SBdP).

Mata pelajaran Seni Budaya dan Prakarya (SBdP) merupakan pendidikan seni berbasis budaya di sekolah dasar yang memiliki tujuan untuk meningkat dan mengembangkan potensi dalam hal ini bakat dan minat siswa secara aktif serta kreatif tanpa harus meninggalkan nilainilai norma dan karakter dari budaya bangsa Indonesia. Untuk mengetahui atau mengukur tercapai atau tidaknya tujuan dari proses pembelajaran secara kualitas, guru perlu melakukan sebuah penilaian atau evaluasi terhadap hasil belajar siswa. Dalam melakukan penilaian atau evaluasi, diperlukan sebuah alat yang disebut sebagai instrumen penilaian.

Penggunaan instrumen penilaian pada mata pelajaran SBdP faktanya belum maksimal. Sebuah hasil studi penelitian yang dilakukan Lius, dkk. (2019: 55-60) menyatakan bahwa guru dalam melakukan penilaian hasil karya seni rupa siswa masih berdasarkan perasaan dan belum mengacu pada instrumen serta indikator-indikator yang jelas. Selain itu, proses penilaian pada aspek psikomotor khususnya pembelajaran seni rupa guru melakukan evaluasi atau penilaian hasil unjuk kerja siswa secara langsung dan secara umum saja tanpa menggunakan rubrik penilaian proses maupun rubrik penilaian produk yang sesuai dengan kompetensi (Puspita, dkk., 2016; Asriningtyas, V., dan Supahar, 2016).

Uraian data diatas juga didukung oleh hasil wawancara dengan Ibu Widi selaku guru wali kelas III di SD Negeri 01 Pelutan menunjukan bahwa tidak adanya rubrik atau instrumen penilaian merupakan akar dari masalah-malasah tersebut. Oleh karena itu, perlu pengembangan sebuah instrumen penilaian untuk menyelesaikan masalah tersebut. Instrumen penilaian yang dikembangkan adalah sebuah instrumen penilaian yang berisi mengenai indikatorindikator yang ingin dicapai pada pembelajaran seni rupa khususnya keterampilan menggambar dan mewarnai.

Berdasarkan permasalahan diatas, penelitan ini bertujuan untuk mengembangkan sebuah instrumen penilaian keterampilan menggambar dan mewarnai agar dapat digunakan oleh guru sebagai pedoman penilaian pada saat pembelajaran di kelas. Serta untuk mengetahui kelayakan instrumen 
penilaian keterampilan menggambar dan mewarnai untuk siswa kelas III pada mata pelajaran SBdP. Sehingga, penelitian ini akan menghasilkan sebuah instrumen penilaian keterampilan menggambar dan mewarnai yang didalamnya meliputi kisikisi instrumen penilaian, lembar kerja siswa, lembar penilaian dan rubrik penilaian untuk siswa kelas III sekolah dasar yang sebelumnya belum pernah dikembangkan.

\section{KAJIAN PUSTAKA}

\section{Instrumen Penilaian}

Andarini Permata (2020) mengemukakan bahwa "evaluation is a process to decide the progress of the subject by comparing it to the predetermined goals and efforts to obtain feedback for future improvements." Penilaian atau evaluasi merupakan kegiatan yang dilakukan untuk memutuskan hal apa yang perlu dilakukan selanjutnya sebagai perbaikan siswa dan upaya untuk mendapatkan umpan balik dengan didasarkan pada pembandingan antara kemajuan didapatkan siswa dengan tujuan yang telah ditentukan sebelumnya. Dalam melakukan penilaian dibutuhkan adanya instrumen.

Instrumen penilaian adalah sebuah alat yang digunakan guru untuk mengukur dan mengumpulkan data serta informasi mengenai pencaipaian dari kompetensi yang ingin dicapai oleh siswa berdasarkan indikator dari tujuan pembelajaran. Instrumen penilaian merupakan alat bantu guru yang berbentuk benda. Wujud dari instrumen penilaian dapat berupa angket, skala, pedoman wawancara, soal tes, dan lain-lain.

Dalam melakukan proses evaluasi atau penilaian harus diperhatikan prinsip dari penilaian hasil belajar terlebih dahulu. Di dalam Pemendikbud RI No. 23 Tahun 2016 tentang standar penilaian Pendidikan, disebutkan bahwa terdapat beberapa prinsip dalam melakukan penilaian hasil belajar siswa. Prinsip-prinsip tersebut yaitu terdiri dari Sahih, Objektif, Adil, Terpadu, Terbuka, Menyeluruh dan berkesinambungan, Sistematis, Beracuan kriteria, dan Akuntabel.

Pelaksanaan penilaian di SD dilakukan sesuai dengan kurikulum 2013 dimana penilaian hasil belajar siswa dilakukan mencangkup seluruh kompetensi dasar yang dibedakan menjadi tiga aspek yaitu aspek kognitif (pengetahuan), aspek afektif (sikap), dan aspek psikomotor (keterampilan). (Permendikbud Tahun 2016 No.23). Dalam pelaksanaannya, penilaian aspek kognitif dan aspek afektf dapat dilakukan melalui beberapa teknik yaitu tes tertulis, tes lisan, penugasan observasi, penilaian diri, penilaian antarsiswa, dan jurnal catatan hasil pengamaan. Pada aspek psikomotor teknik penilaian yang dapat digunakan adalah penilaian kinerja, penilian proyek, penilaian produk dan portofolio.

Produk yang akan dikembangkan pada penelitian ini adalah instrumen penilaian dengan teknik penilaian produk. Penilaian produk adalah teknik penilaian yang akan menilai kemampuan atau keterampilan siswa dalam bereksplorasi dan mengembangkan gagasan dalam mendesain dalam mendesain, memilih bahan-bahan yang tepat, menggunakan alat, menunjukkan inovasi dan kreasi dan memilih bentuk 
dan gaya dalam karya seni. Penilaian jenis ini

Dalam mengembangkan sebuah instrumen penilaian harus memperhatikan beberapa kriteria yang telah diatur dalam Permendibud No. 66 Tahun 2013 tentang standar penilaian. Instrumen penilaian yang digunakan harus memenuhi syarat sebagai berikut:

a. Substansi yang mempresentasikan kompetensi yang akan dinilai

b. Konstruksi yang memenuhi persyaratan teknis sesuai dengan bentuk instrumen yang digunakan.

c. Penggunaan Bahasa yang baik dan benar serta komunikatif sesuai dengan tingkat pekembangan para peserta didik.

\section{Pendidikan Seni Rupa di SD}

Pendidikan seni di SD digunakan sebagai media atau sarana untuk menumbuhkan dan mengembangkan kreativitas yang dimiliki oleh siswa. Pendidikan seni sendiri termasuk kedalam muatan pelajaran Seni Budaya dan Prakarya (SBdP). Sistem pengajaran seni di sekolah lebih menekankan pada aspek psikomotor dan afektif, dimana proses belajar mengajar seni di kelas lebih menitikberatkan pada praktik berkarya dan mengapresiasi karya seni.

Terdapat tiga cabang seni yang diajarkan pada muatan pelajaran SBdP yaitu seni musik, seni tari dan seni rupa. Keterampilan menggambar dan mewarnai ini termasuk kedalam kelompok cabang seni rupa. Sumanto (2016) mengemukakan beberapa aspek-aspek subtansial yang didasarkan pada kompetensi yang ingin di capai pada pembelajaran seni rupa di sekolah dasar. Aspek substansial tersebut yaitu:

a. Ide dasar mengolah seni, dengan adanya kompetensi ini diharapkan siswa dapat mengungkapkan ide-ide yang ada di dalam pikirannya melalui karya seni.

b. Merancang karya seni, disini siswa diharapkan agar agar merancang atau mendesain sebuah karya yang ingin diciptakan sesuai dengan keinginan atau imanijinasi masing-masing siswa.

c. Membuat karya seni, siswa diharapkan dapat membuat atau mencipatakan sebuah produk karya seni sesuai dengan apa yang diinginkan. Produk karya seni dapat berupa gambar, lukisan, patung, dan lain-lain.

d. Menyajikan hasil karya seni, siswa diharapkan dapat mempresentasikan atau melaporkan bagaimana proses yang telah dilalui dalam berkarya seni baik melalui lisan maupun tulisan.

e. Mengapresiasi karya seni, dalam hal ini siswa diharapkan dapat menilai atau mengevaluasi bisa dengan memberikan kiritik dan saran pada hasil karya seni siswa lainnya.

\section{Keterampilan Menggambar dan}

\section{Mewarnai}

Menggambar dapat diartikan sebagai kegiatan yang sering kali dilakukan oleh anak untuk mengungkapkan apa yang ada pikirannya secara keratif dan imajinatif dalam bentuk coretan dan goresan. Kegiatan menggambar sendiri memiliki manfaat untuk 
meningkatkan kreativitas dan mengembangkan daya imajinasi yang dimiliki oleh anak. Sedangkan mewarnai adalah suatu kegiatan memberikan warna pada sebuah gambar dengan menggunakan media tertentu seperti pensil warna, cat air, dan sebagainya. Menggambar dan mewarnai sangat berkaitan erat dan tidak bisa dipisahkan begitu saja, karena sebuah gambar akan lebih menarik jika diberikan unsur warna di dalamnya. Dengan adanya warna pada sebuah gambar akan menjadikan karya gambbar tersebut lebih hidup dan lebih indah sehingga dapat diapresiasi oleh orang lain.

\section{METODE PENELITIAN}

Desain penelitian yang digunakan pada penelitian ini adalah penelitian dan pengembangan atau biasa dikenal penelitian Research $\mathcal{E}$ Development (R\&D). Penelitian ini dilakukan sesuai dengan metode penelitian yang dikemukakan oleh Brog and Gall (1989). Metode penelitian R \& D ini meliputi sepuluh langkah, yakni:
(1) Research
and
Information
colletion, (2) Planning,
(3) Develop

Preliminary form of Product, (4) Preliminary Field Testing, (5) Main Product Revision, (6) Main Field Testing, (7) Operational Product Revision, (8) Operational Field Testing, (9) Final Product Revision, dan (10) Disemination and Implementasi.

Pada tahap Preliminary Field Testing atau ujicoba lapangan terbatas yang dilakukan oleh 3 tim penilai ahli yang berkerja sebagai dosen PGSD di Universitas Islam Sutan Agung untuk memvalidasi produk instrumen penilaian yang dikembangkan pada peleitian ini. Untuk menghitung skor hasil validasi ahli instrumen penilaian pada penelitian ini menggunakan rumus yang dikemukakan oleh Aiken's.

$$
\mathrm{V}=\frac{\Sigma s}{N(c-1)}
$$

$$
\begin{aligned}
& \text { Keterangan : } \\
& \mathrm{V} \quad \text { : Validasi } \\
& \mathrm{N} \quad \text { : Banyaknya ahli } \\
& \mathrm{S} \quad \text { : Skor per kategori - Skor terendah } \\
& \mathrm{C} \quad \text { : Skor tertinggi }
\end{aligned}
$$

Setelah diperoleh skor diperoleh, kemudian skor atau data didapatkan disesuaikan dengan kriteria kelayakan yang telah ditetapkan.

\begin{tabular}{cc}
\multicolumn{2}{c}{ Tabel 1. Kriteria Kelayakan } \\
\hline Skor & Kategori \\
\hline $0,80-1,00$ & Sangat Tinggi \\
$0,60-0,80$ & Tinggi \\
$0,40-0,60$ & Cukup \\
$0,20-0,40$ & Rendah \\
$0,00-0,20$ & Sangat Rendah \\
\hline \multicolumn{2}{c}{ Sumber : Azwar (Madliyah, S., } \\
Abdurachman, F., Hartono:2017)
\end{tabular}

Data yang didapatkan dengan melihat respon guru dan respon siswa pada tahap main field testing (ujicoba lapangan skala terbatas) dan operational field testing (ujicoba lapangan skala luas) dengan memberikan angket, kemudian akan dianalisis kuantitatif menggunakan rumus dibawah ini :

$$
\begin{aligned}
& \text { Persentase (\%) }=\frac{\text { Jumlah Skor Total }(x)}{\text { Jumlah Skor Maximum }(x i)} \times 100 \% \\
& \text { Hasil perhitungan kuantitatif } \\
& \text { berdasarkan rumus diatas, kemudian } \\
& \text { menentukan kriteria kelayakan sebuah } \\
& \text { instrumen penilaian dengan ketentuan } \\
& \text { sebagai berikut: }
\end{aligned}
$$


Tabel 2. Kriteria Kelayakan

\begin{tabular}{cc}
\hline Skor & Kategori \\
\hline $81 \%-100 \%$ & Sangat Layak \\
$61 \%-80 \%$ & Layak \\
$41 \%-60 \%$ & Cukup Layak \\
$21 \%-40 \%$ & Kurang Layak \\
$0 \%-20 \%$ & Sangat Tidak Layak \\
\hline
\end{tabular}

Selain dibantu oleh tiga validator ahli, untuk mengumpulkan data penelitian ini juga dibantu oleh 3 orang guru kelas III sekolah dasar di SD N 01 Pelutan dan 15 orang siswa kelas III sekolah dasar.

\section{HASIL DAN PEMBAHASAN}

\section{Hasil Penelitian}

Penelitian ini dilakukan untuk mengembangkan sebuah insrumen penilaian menggambar dan mewarnai. Dalam mengembangkan produk tersebut tahap-tahap yang dilakukan adalah sebagai berikut.

\section{a. Research and Information colletion}

Pada langkah ini dilakukan dua kegiatan, yaitu studi literatur dan studi lapangan. Studi literasi yang dilakukan pada penelitian ini menemukan bahwa terdapat beberapa penelitian serupa yang berfokus pada mengembangkan sebuah instrumen penilaian tetapi belum ada penelitian yang secara spesifik membahas mengenai pengembangan instrumen penilaian menggambar dan mewarnai siswa kelas III sekolah dasar. Sedangkan studi lapangan sendiri dilakukan dengan wawancara bersama Ibu Widi selaku wali kelas III yang menyebutkan bahwa sekolah belum memiliki instrumen penilaian yang secara spefisik digunakan untuk menilai keterampilan menggambar dan mewarnai siswa kelas III. Guru kelas III di SD Negeri 01 Pelutan hanya menggunakan kriteria secara umum untuk menilai keterampilan ataupun karya yang dimiliki oleh siswa.

\section{b. Planning}

Pada langkah ke dua ini akan disusun sebuah rencana pelaksanaan penelitian yang meliputi kemampuan yang diperlukan dalam melakukan penelitian, menentukan desain atau metode penelitian yang akan digunakan dalam penelitian ini akan menggunakan metode penelitian $\mathrm{R}$ \& D yang dikemukakan oleh Brog and Gall, dan menentukan subjek serta objek penelitian yang akan membantu dalam pelaksanaan penelitian ini yaitu guru dan siswa kelas III sekolah dasar.

c. Develop Preliminary form of Product

Pada tahap ini, akan dikembangkan draft instrumen penilaian yang berupa pengembangan produk kisi-kisi instrumen penilaian, rubrik penilaian dan penskoran, lembar instrumen penilaian dan lembar kerja siswa. Selain mengembangkan draft instrumen penilaian, pada tahap ini dikembangkan juga angket validasi yang nantinya digunakan untuk mengevaluasi kualitas produk.

\section{d. Preliminary Field Testing}

Produk yang sudah dirancang sebelumnya akan dikaji dan dievaluasi oleh validator atau tim penilai produk secara terbatas oleh tiga orang ahli yaitu Ibu Nuyal Ulia, M.Pd., Ibu Sari Yustiana, M.Pd., dan Ibu Yunita Sari, M.Pd. yang merupakan dosen dari prodi PGSD Universitas Islam Sultan Agung Semarang.

Hasil validasi untuk kisi-kisi instrumen penilaian, lembar kerja siswa, lembar penilaian dan rubrik penilaian adalah sebagai berikut. 
Tabel 3. Hasil Validasi Ahli

\begin{tabular}{|c|c|c|}
\hline Produk & $\begin{array}{c}\text { Koefisien } \\
\text { (V) }\end{array}$ & Kategori \\
\hline $\begin{array}{l}\text { Kisi-kisi } \\
\text { Instrumen } \\
\text { Penilian }\end{array}$ & 0,85 & $\begin{array}{l}\text { Sangat } \\
\text { Tinggi }\end{array}$ \\
\hline $\begin{array}{l}\text { Lembar } \\
\text { Kerja Siswa }\end{array}$ & 0,78 & Tinggi \\
\hline $\begin{array}{l}\text { Lembar } \\
\text { Penilaian }\end{array}$ & 0,88 & $\begin{array}{l}\text { Sangat } \\
\text { Tinggi }\end{array}$ \\
\hline $\begin{array}{c}\text { Rubrik } \\
\text { Penilaian }\end{array}$ & 0,80 & $\begin{array}{l}\text { Sangat } \\
\text { Tinggi }\end{array}$ \\
\hline Total & 0,81 & $\begin{array}{l}\text { Sangat } \\
\text { Tinggi }\end{array}$ \\
\hline
\end{tabular}

Dari data diatas dapat disimpulkan bahwa keempat jenis produk yang dikembangkan dinyatakan valid dengan rincian skor validasi sebesar kisi-kisi instrumen penilaian adalah 0.85 dengan kategori sangat tinggi, lembar kerja siswa adalah 0.78 termasuk kedalam kategori tinggi, lembar penilaian mendapat skor 0.82 dengan kategori sangat tinggi dan untuk rubrik penilaian skornya adalah 0,80 yang termasuk kedalam kategori sangat tinggi.

\section{e. Main Product Revision}

Pada tahap ini terdapat beberapa item atau aspek yang perlu direvisi yaitu :

1) Pada kisi-kisi instrumen penilaian dilakukan penambahan indikator pada kisi-kisi agar tidak hanya 1 indikator dan lebih memperhatikan penulisan kata.

2) Pada lembar kerja siswa ditambahkan lembar jawaban untuk siswa karena sebelumnya belum ada lembar jawab yang dapat digunakan siswa untuk mengerjakan kegiatan yang diberikan.
3) Pada lembar penilaian, diberikan saran oleh validator yaitu lebih konsistensi dalam penggunaan istilah. Konsistensi yang dimaksud adalah dalam penggunaan istilah dari awal instrumen hingga akhir istilah yang digunakan harus sama atau selaras tidak boleh berubahubah. Istilah yang tidak konsisten tersebut adalah penggunaan kata "peserta didik" yang beberapa kali menggantikan kata "siswa".

4) Pada rubrik penilaian diberikan penambahan petunjuk penggunaan pada rubrik penilaian agar mudah digunakan dan sudah ditambahkan petunjuk penggunaannya.

\section{f. Main Field Testing}

Pada Tahap ini dilakukanlah ujicoba lapangan skala terbatas atau bisa dikatakan ujicoba skala kecil dengan dua jenis responden yaitu 1 guru wali kelas III dan 5 orang siswa kelas III yang diberikan angket secara daring. Hasil yang diperoleh pada ujicoba skala kecil yaitu untuk angket respon guru mendapatkan skor 102 dengan presentase $81,6 \%$ dan termasuk kedalam kategori "Sangat Layak". Dan untuk angket respon siswa mendapatkan skor 9,8 dengan presentase $98 \%$ yang termasuk kedalam kategori "Sangat Layak".

Responden siswa yang dimembantu dalam ujicoba skala terbatas ini hanya 5 orang siswa dikarenakan terdapat kendala dimana kondisi dan situasi pada saat penelitian tidak memungkinkan untuk berkumpul dengan banyak orang sehingga penelitian hanya dilakukan pada 5 orang siswa secara terbatas.

\section{g. Operational Product Revision}

Berdasarkan data yang diperoleh dari tahap ujicoba skala terbatas tidak 
terdapat revisi baik dari hasil angket respon guru maupun dari angket respon siswa.

\section{h. Operational Field Testing}

Uji coba ini dilakukan dengan subjek penelitian sebanyak kurang lebih 10 siswa kelas III dari SD N 01 Pelutan dan dua guru kelas III sekolah dasar. Hasil yang didapatkan pada tahap ini yaitu untuk angket respon guru skor 108 untuk angket respon guru 1 dan guru 2 mendapatkan skor 109. Jumlah skor rata-rata yang didapatkan pada ujicoba skala besar ini adalah 108,5 dan presentase yang dihasilkan sebesar $86,8 \%$ dengan kategori "Sangat Layak". Dan untuk angket respon siswa yang digunakan untuk mengevaluasi lembar kerja siswa mendapatkan skor rata-rata sebanyak 100 dengan presentase $100 \%$. Hasil tersebut termasuk kedalam kategori "Sangat Layak". Berdasarkan data diatas, instrumen penilaian menggambar dan mewarnai dinyatakan layak dan praktis untuk digunakan pada saat pembelajaran SBdP.

\section{i. Final Product Revision}

Instrumen penilaian menggambar dan mewarnai berdasarkan pada ujicoba skala luas tidak ada revisi atau perbaikan yang diberikan oleh guru maupun siswa yang menjadi responden pada ujicoba skala luas.

\section{j. Disemination and Implementasi}

Tahap ini dilakukan dengan memperkenalkan dan menjelaskan cara pakai produk yang dihasilkan dari penelitian ini berupa instrumen penilaian yang terdiri dari kisi-kisi intrumen penilaian, lembar kerja siswa, lembar penilaian dan rubrik penlaian kepada guru kelas III SD. Sekolah dasar yang menjadi tujuan dalam melakukan tahap desiminasi dan implementasi adalah SD Negeri 01 Pelutan dan SD N 04 Tanjungsari.

\section{Pembahasan}

Produk yang dihasilkan pada penelitian ini adalah instrumen penilaian menggambar dan mewarnai kelas III sekolah dasar yang terdiri dari 4 jenis produk yaitu kisi-kisi instrumen penilaian, lembar kerja siswa, lembar penilaian, dan rubrik penilaian. Instrumen penilaian valid dan layak digunakan setelah melalui beberapa kali ujicoba. Ujicoba tersebut menggunakan angket untuk mengetahui kelayakan dari instrumen penilaian. Ujicoba tersebut dilakukan oleh 3 validator yang terdiri dari dosen PGSD Universitas Islam Sultan Agung Semarang yang mengisi angket validasi, 3 guru kelas III sekolah dasar dan 15 siswa kelas III sekolah dasar dengan mengisi angket untuk melihat respon instrumen penilaian yang dikembangkan.

Dalam mengembangkan sebuah instrumen penilaian menggambar dan mewarnai siswa dengan melalui 10 tahapan penelitian. Penelitian ini diawali dengan mencari dan mengumpulkan informasi atau data awal yang sesuai dengan topik penelitian di SD N 01 Pelutan. Data awal yang telah didapatkan kemudian digunakan untuk merencanakan bagaimana melaksanakan penelitian tersebu akan dilakukant. Tahap planning atau merancanakan ini dilakukan untuk mengurutkan langkah-langkah agar penelitian lebih sistematis seperti menentukan tahapan penelitan yang akan digunakan. Tahapan yang digunakan pada penelitian ini adalah tahapan yang dikemukan oleh Brog and Gall. Selain itu adalah memilih responden untuk penelitian. Responden yang membantu 
dalam penelitian ini adalah 3 guru kelas III dan 15 siswa kelas III sekolah dasar.

Ketiga, tahap develop preliminary form of product yang dimaksudkan untuk menyusun atau mengembangkan sebuah produk. Produk yang dikembangkan pada penelitian ini adalah instrumen penilaian yang didalamnya mencangkup kisi-kisi, lembar kerja siswa, lembar penilaian, dan rubrik penilaian. Instrumen penilaian ini disusun dengan menyesuaikan KI dan KD yang ada pada muatan pelajaran SBdP. Setelah produk tersebut dikembangkan, tahap selanjutnya yaitu preliminary field testing atau ujicoba lapangan secara terbatas. Ujicoba ini hanya dilakukan oleh 3 orang ahli atau biasa disebut validator. Tahap ujicoba lapangan secara terbatas dilakukan dengan menunjukan produk yang telah dikembangkan kepada validator. Nantinya setelah dilakukan ujicoba secara terbatas, validator akan memberikan beberapa revisi dan saran yang berguna bagi perbaikan produk yang akan dikembangkan.

Tahap selanjutnya adalah Main Product Revision atau revisi utama produk. Revisi atau perbaikan produk ini dilakukan sesuai dengan saran yang berikan oleh validator. Terdapat 4 hal yang perlu direvisi dari produk instrumen penilaian ini, yaitu:

a. Penambahan indikator pada kisi-kisi agar tidak hanya 1 indikator dan lebih memperhatikan penulisan kata.

b. Pada lembar kerja siswa ditambahkan lembar jawaban untuk siswa

c. Lebih konsistensi dalam penggunaan istilah.

d. Pada rubrik penilaian diberikan penambahan petunjuk penggunaan

Setelah memperbaiki produk sesuai dengan hasil revisi yang diberikan oleh validator, tahap selanjutnya adalah main field testing atau ujicoba lapangan berskala terbata. Ujicoba berskala terbatas ini dilakukan terhadap beberapa responden yaitu 1 guru dan 5 siswa kelas III sekolah dasar. Tahap selanjutnya adalah operational product revision atau revisi produk. Pada tahap ini perbaikan tidak dilakukan karena berdasarkan hasil ujicoba berskala terbatas tidak ada revisi baik yang diberikan oleh guru maupun siswa.

Tahap selanjutnya adalah operational field testing atau ujicoba lapangan dengan skala luas dengan menggunakan 10 responden dari siswa dan 2 responden dari guru. Jika terdapat hal-hal yang perlu diperbaiki maka tahap selanjutnya adalah final product revision atau revisi final produk. Pada penelitian ini tidak terdapat revisi yang diberikan sehingga bisa melanjutkan ke tahap terakhir yaitu tahap disemination and implementasi. Pada tahap terakhir ini, produk yang telah dikembangkan berupa instrumen penilaian keterampilan menggambar dan mewarnai diperkenalkan dan diberikan kepada SD N 01 Pelutan dan SD N 04 Tanjungsari sehingga dapat digunakan pada saat pembelajaran SBdP berlangsung.

Instrumen penilaian keterampilan menggambar dan mewarnai dapat dinyatakan valid dan layak apabila telah mendapatkan penilaian dan evaluasi dari validator atau tim ahli. Selain dari validasi ahli, layak atau tidaknya produk juga didukung dari data angket respon yang diberikan kepada guru dan siswa untuk menguatkan kelayakan produk instrumen penilaian keterampilan menggambar dan mewarnai ini.

Kelayakan instrumen penilaian keterampilan menggambar dan mewarnai ini mendapatkan skor untuk kisi-kisi sebesar 0,92, lembar kerja siswa adalah 0,81 , lembar penilaian mendapat skor 0,88 dan untuk rubrik penilaian skornya adalah 
0,84. Jumlah rata-rata untuk hasil validasi dari keseluruhan instrumen penilaian adalah 0,86 dengan kategori "Sangat Tinggi". Berdasarkan hasil validasi tersebut maka instrumen penilaian keterampilan menggambar dan mewarnai siswa dinyatakan valid dan layak untuk digunakan.

Data yang didapatkan dari validasi ahli dapat diperkuat melalui ujicoba skala terbatas dan skala luas untuk mengetahui kelayakan dan kualitas instrumen saat diujicobakan di lapangan. Ujicoba skala terbatas yang dilakukan dengan melihat respon guru dan 5 siswa atau responden. Hasil dari respon guru mendapatkan skor presentase $81,6 \%$ dan termasuk kedalam kategori "Sangat Layak" tanpa revisi. Sedangkan respon siswa pada ujicoba skala terbatas untuk mengevaluasi lembar kerja siswa mendapatkan skor presentase 98\% yang termasuk kedalam kategori "Sangat Layak". Ujicoba berskala berbatas yang dilakukan pada siswa juga tidak terdapat revisi sehingga penelitian ini dilanjutkan kepada ujicoba berskala luas.

Ujicoba berskala luas ini dilakukanpada guru kelas III dan 10 siswa kelas III. Hasil ujicoba berskala luas yang dilakukan kepada guru mendapatkan skor sebesar $86,8 \%$. Skor dari hasil respon guru termasuk kategori "Sangat Layak" tanpa adanya revisi yang diberikan dari guru. Untuk hasil ujicoba berskala luas dari respon siswa mendapatkan skor sebesar $100 \%$ yang masuk ke dalam kategori "Sangat Layak". Pada ujicoba berskala luas ini produk tidak mendapatkan revisi dari siswa.

Penelitian mengenai pengembangan instrumen juga pernah dilakukan oleh Putriyani dan Mutmainnah (2018) yang mengembangkan instrumen penilaan autentik yang bersifat valid dan reliabel karena sudah memenuhi kriteria yang telah ditentukan. Hanya saja untuk pengembangan instrumen penilaian yang berfokus pada penilaian keterampilan menggambar dan mewarnai sangat jarang ada yang mengembangkan atau membuat. Disekolah pun instrumen penilaian untuk menilai keterampilan menggambar dan mewarnai sangat jarang ada yang menyusun atau mengembangkannya. Disekolah, guru hanya menggunakan beberapa kriteria standar dalam menggambar tanpa memperhatikan indikator yang ingin dicapai secara lebih dalam.

Dengan adanya instrumen penilaian untuk menilai keterampilan menggambar dan mewarnai siswa kelas III yang dikembangkan pada penelitian ini bisa sangat berguna. Berguna yang dimaksud adalah instrumen penilaian ini akan bermanfaat bagi guru karena dapat membantu dalam melakukan penilaian keterampilan menggambar dan mewarnai yang sesuai dengan indikator yang ingin dicapai pada pembelajaran. Instrumen penilaian yang dikembangkan telah disesuaikan dengan kompetensi dasar dan indikator pada muatan pelajaran seni budaya dan prakarya kelas III sekolah dasar. Maka dari itu, instrumen penilaian dapat berguna bagi guru dalam menilai hasil karya dan keterampilan menggambar serta mewarnai siswa.

\section{SIMPULAN}

Pengembangan instrumen penilaian menggambar dan mewarnai siswa dilakukan dengan 10 langkah desain penelitian Brog and Gall yang terdiri dari (1) Research and Information colletion, (2) Planning atau merencanakan penelitan yang akan dilakukan, (3) Develop Preliminary form of Product yaitu dengan mengembangkan desain dan produk., (4) Preliminary Field Testing dilakukan 
untuk mengevaluasi atau memvalidasi produk secara terbatas oleh tiga tim ahli, (5) Main Product Revision dimana akan dilakukan revisi atau perbaikan sesuai dengan saran dan kritik dari validator, (6) Main Field Testing dilakukan dengan menguji coba produk tetapi skala ujicoba tersebut terbatas dengan satu guru kelas III dan 5 siswa kelas III, (7) Operational Product Revision yaitu revisi tahap kedua yang dilakukan berdasarkan hasil dari ujicoba skala terbatas, (8) Operational Field Testing ini merupakan ujicoba terakhir dengan skala yang lebih luas dengan dua guru kelas III dan 10 siswa kelas III, (9) Final Product Revision ini merupakan perbaikan tahapn terakhir atau revisi produk terakhir sebelum produk tersebut disebarkan, dan (10) Disemination and Implementasi dengan cara memperkenalkan dan memberikan produk tersebut kepada 2 sekolah dasar yaitu SD Negeri 01 Pelutan dan SD Negeri 04 Tanjungsari. Produk yang telah dikembangkan tersebut adalah Instrumen penilaian keterampilan menggambar dan mewarnai unuk siswa kelas III sekolah dasar.

Produk yang telah dikembangkan yaitu instrumen penilaian keterampilan menggambar dan mewarnai dapat dinyakan valid dan layak digunakan dalam proses pembelajaran. Hal tersebut dapat dibuktikan dengan uraian sebagai berikut.

1) Instrumen penilaian keterampilan menggambar dan mewarnai mendapatkan kriteria "Sangat Tinggi" dengan nilai koefisien rata-rata sebesar 0,864 dengan rincian skor untuk kisikisi sebesar 0,920, lembar kerja siswa adalah 0,812, lembar penilaian mendapat skor 0,884 dan untuk rubrik penilaian skornya adalah 0,840 .

2) Instrumen penilaian keterampilan menggambar dan mewarnai dapat dinyatakan valid dan layak digunakan saat proses pembelajaran setelah diakukan dua kali ujicoba yaitu :

a. Ujicoba skala terbatas yang mendapatkan hasil dari respon guru sebesar $81,6 \%$ dan termasuk kedalam kategori "Sangat Layak" tanpa revisi. Dan untuk respon siswa terhadap lembar kerja siswa mendapatkan $98 \%$ yang termasuk kedalam kategori "Sangat Layak".

b. Ujicoba skala luas mendapatkan skor sebesar 86,8\% dengan kategori "Sangat Layak" tanpa adanya revisi dari respon guru. Untuk hasil ujicoba berskala luas dari respon siswa mendapatkan skor sebesar $100 \%$ yang masuk ke dalam kategori "Sangat Layak".

\section{DAFTAR PUSTAKA}

Asriningtyas, V., dan Supahar. (2016). "Pengembangan Instrumen Penilaian Aspek Afektif Dan Psikomotor Peserta Didik Pada Model Pembelajaran Kooperatif Metode Two Staytwo Stray Dalam Mata Pelajaran Fisika SMA". Jurnal Pendidikan Fisika. Volume 5, (5), 284-293.

Cahyaningtyas, A. P., Sari, Y., \& Pradana, A. B. A. (2020). HIGH ORDER THINKING SKILLS: HOW IS IT INTEGRATED WITH COGNITIVE ASSESSMENT?. Jurnal Ilmiah Pendidikan Dasar, 7(2), 109-120.

Effendi, H., Hendriyani, Y. (2016). "Pengembangan Model Blended Learning Interaktif dengan Prosedur Borg And Gall". INTERNATIONAL SEMINAR ON EDUCATION (ISE) 2 $n d$. 
Hardiani, I.N. (2017). “Pengembangan Instrumen Penilaian Sikap Sosial Pembelajaran IPS Kelas IV SD". Ejurnal Mitra Pendidikan. 1, (6), 615628.

Kemendikbud. (2013). Peraturan Mentri Pendidikan dan Budaya No. 66 tentang Standar Penilaian. Jakarta: Kemendikbud

Kemendikbud. (2016). Peraturan Mentri Pendidikan dan Budaya No. 23 tentang Standar Penilaian Pendidikan. Jakarta: Kemendikbud

Kurniawaty, M.D. (2017). Pengembangan Instrumen Penilaian Berbasis Kinerja Pada Pembelajaran Tematik Siswa Kelas IV Sekolah Dasar. Tesis pada FKIP Universitas Lampung: tidak diterbitkan

Lius, C.R., Witri, G., dan Putra, J.A. (2019). Studi Pendahuluan Pengembangan Instrumen Keterampilan Guru dalam Penilaian Portofolio Mata Pelajaran SBdP. Prosiding Seminar Nasional Pendidikan Guru Sekolah Dasar. Hal.55-60. ISBN: 978-62391681-0-0, DOI: http://dx.doi.org/10.33578/psn.v1i1. $\underline{7778}$

Madliyah, S., Abdurachman, F., dan Hartono. (2017). “Pengembangan Instrumen Penilaian Keterampilan Proses Sains Dasar Mata Pelajaran Kimia Pada Kompetensi Dasar Kelarutan dan Hasil Kali Kelarutan di SMA". Prosiding Seminar Nasional Pendidikan IPA. Halaman 327-337.

Nur, S.M. (2015). “Pengembangan Perangkat Penilaian Psikomotorik Pada Peserta Didik". Jurnal Biotek. 3. (1). 151-169.
Putriyani., Mutmainnah.

(2018). "Pengembangan Instrumen Penilaian Autentik Pada Pembelajaran Dengan Pendekatan Scientific. Jurnal Pendidikan: Edumaspul. 2, (1), 1-10.

Rentnowati, T.H., dkk. (2016). "Pengembangan Instrumen Penilaian Proses Karya Seni Lukis Terintegrasi Dengan Karakter Untuk Menilai Praktik Kerja Lapangan Peserta Didik Sekolah Menengah Kejuruan". Prosiding Seminar Nasional:"Meneguhkan Peran Penelitian dan Pengabdian kepada Masyarakat dalam Memuliakan Martabat Manusia". Halaman 180189.

Sumanto. (2016). "Penilaian Kinerja Perilaku Berkesenian Siswa Sekolah Dasar". Prosiding Seminar Nasional KSDP Prodi S1 PGSD: Konsentrasi Pendidikan dan Kebudayaan Indonesia di Era Globalisasi.

Yuberti. (2014). "Penelitian dan Pengembangan Yang Belum Diminati Dan Perspektifnya". Jurnal Ilmiah Pendidikan Fisika AlBiruni. 3, (2), 1-15.

Yuniarti, B., Fatmaryanti, S.D., dan Maftukhin, A. (2014). "Pengembangan Instrumen Penilaian Psikomotorik pada Pelaksanaan Praktikum Fisika Siswa Kelas X SMA Negeri 5 Purworejo Tahun Pelajaran 2013/2014". Radiasi. 5, (1), 77-81. 